\title{
Когнітивний та нейросенсорний дефіцит різного генезу: як не пропустити головне
}

\section{Л.А. Дзяк}

Державний заклад «Дніпровський державний медичний університет», Дніпро, Україна

Стрімке поширення захворювань, які супроводжуються порушеннями інтегративних процесів у центральній нервовій системі (ЦНС), що є основою вищих психічних функцій, визначає інтерес до цієї актуальної проблеми сучасності. Когнітивні функції дозволяють швидко та легко адаптуватися до інформації, що потрапляє, і до змін оточуючого середовища, здійснювати зв'язок з навколишнім світом, забезпечуючи цілеспрямовану взаємодію 3 ним (рис. 1).

Рисунок 1 Вищі психічні функції

\begin{tabular}{|c|c|}
\multicolumn{3}{|c|}{ Емоційні та вольові процеси } \\
\hline Почуття \\
Емоції \\
& Пізнавальні процеси \\
& Відчуття \\
Сприйняття & \\
Увага & Мислення \\
Пам'ять & Уява \\
Настрій & Мова \\
& Інтелект \\
\hline
\end{tabular}

Якщо подивитися на клінічний профіль пацієнта, який звертається на прийом до лікаря-інтерніста, невролога, то можна побачити, що за останній час він значно змінився (рис. 2). Цукровий діабет, артеріальна гіпертензія (АГ), ожиріння, гіперліпідемія являють собою смертельний квартет, до того ж останнім часом коронавірусна хвороба змінила життя пацієнтів і загалом людей на усій планеті. Зазначимо, що всі ці захворювання супроводжуються когнітивними порушеннями, які досягають ступеня деменції. Але деякі з них цукровий діабет, ожиріння, а також, ймовірно, АГ, гіперліпідемія, - призводять до нейродегенеративних захворювань. Ми ще не повною мірою розуміємо, чого слід очікувати від коронавірусної хвороби, але вже зрозуміло, що це захворювання суттєво уражує головний мозок.

Рисунок 2 Клінічний портрет сучасного пацієнта

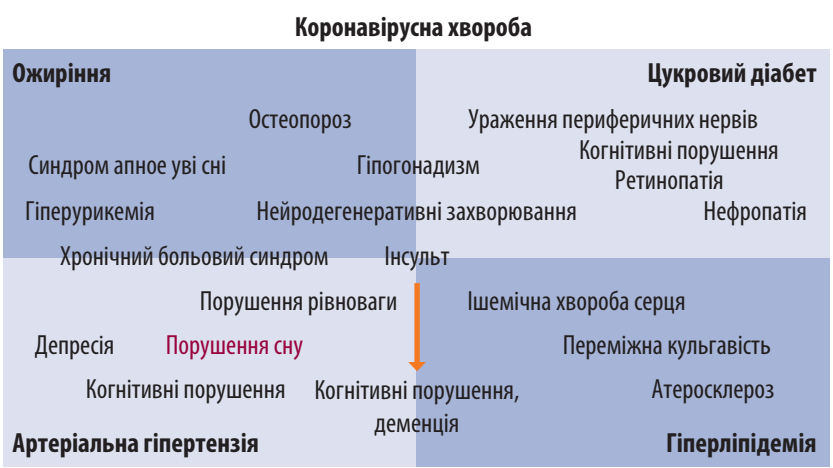

Цукровий діабет, артеріальна гіпертензія ожиріння, гіперліпідемія — смертельний квартет

На жаль, кількість пацієнтів із порушеними вищими психічними функціями збільшується. Порушення когнітивних функцій займає одне з провідних місць серед причин інвалідизації насе- лення, а кількість пацієнтів, що потребують тривалої реабілітації, спрямованої на відновлення психічного здоров'я, залишається значною.

Сучасна діагностика дозволяє уточнити взаємозв'язок патологічного процесу та його наслідків, оцінити характер порушення функції, зміни соціальної та побутової активності, визначити можливості реабілітації таких пацієнтів. Реабілітаційний потенціал відновлення вищих психічних функцій визначається особливостями розвитку і перебігу захворювання, особливостями структурно-функціональних характеристик речовини головного мозку і судинної системи, особливостями саногенезу, можливостями компенсації. Суттєву роль відіграє індивідуальний ресурс пластичності. Величезне значення у розвитку і відновленні психічних функцій має коморбідний профіль пацієнта (рис. 3). Згідно з сучасними уявленнями в основі як істинного відновлення, так і компенсації порушених функцій при ураженнях головного мозку лежать механізми нейропластичності.

Рисунок 3 Реабілітаційний потенціал відновлення психічних функцій

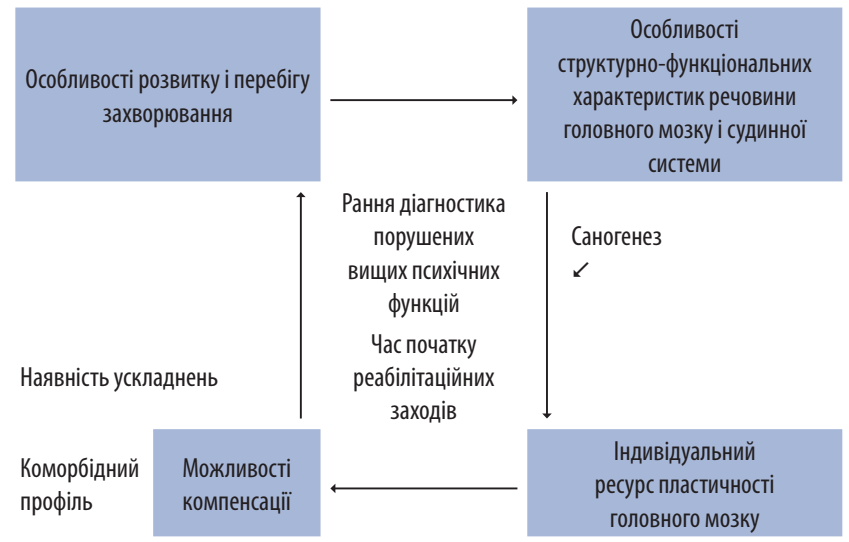

Основні механізми пластичності:

1. Синаптичні:

- зміни існуючих синапсів, в тому числі рівня NMDA і ГАМКергічної трансмісії [1, 2];

- неосинаптогенез.

2. Ріст аксонів та дендритів (англ. sprouting).

3. Нейронеогенез.

4. Системна реорганізація, в тому числі реорганізація нейрональних ланцюгів, - формування нових зв'язків, що забезпечують близькі функції.

Встановлено, що різні відділи головного мозку мають неоднаковий нейропластичний потенціал. Так, кора головного мозку вважається найбільш пластичною часткою ЦНС, що обумовлено різноманіттям клітинних елементів, що її складають, та їх зв'язків. Основою «швидкої нейропластичності» при ураженні головного мозку $є$ активація у неокортексі раніше не задіяних горизонтальних зв'язків, а також модуляція синаптичної передачі $[3,4]$. Це дуже важливо з практичної точки зору, тому що при ураженні коркових відділів відмічають певний темп відновлення, при ураженні підкоркових відділів - реабілітація 
тривала, складна. Різні відділи головного мозку і нейромедіаторні системи мають неоднаковий нейропластичний потенціал. При активації гальмівних ГАМК-ергічних рецепторів відбувається зниження інтенсивності нейропластичних процесів, а активація глутаматергічних NMDA-рецепторів, норадренергічних, дофамінергічних і серотонінергічних рецепторів покращує процеси нейропластичності.

На даний час показано значення порушень аксонального транспорту у генезі нейродегенеративних захворювань. Порушення модуляції і регуляції аксонального транспорту пов'язують з утворенням патологічних білків (білок-попередник амілоїда, тау-білок, пресеніліни та ін.) [5].

Обговорюючи проблему нейропластичності, слід звернути увагу на фактори, які також знижують інтенсивність нейропластичних процесів, - це стресові події, негативні емоції, порушення соціальної взаємодії, самотність, самоізоляція, травматичні події (рис. 4). Активують інтенсивність нейропластичних процесів: позитивні емоції, дієта, новий досвід, фізичні вправи. Ця концепція лягла в основу реабілітаційних заходів у розділі немедикаментозної терапії.

Рисунок 4 Фактори, які впливають на інтенсивність процесів нейропластичності [6-8]

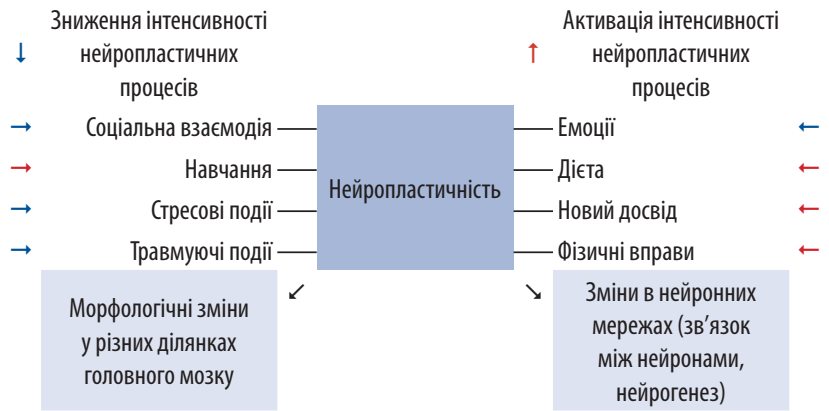

Головний мозок, виявляючи дуже високу функціональну активність, неймовірно вразливий. Показано, що навіть при короткотривалому патогенному впливі відбуваються зменшення об'єму клітин, втрата міжклітинних контактів, зміни мембранних утворень, які призводять до вираженого енергодефіциту, розвитку ішемічного пошкодження структур головного мозку, порушення інтегративної діяльності головного мозку. Це відбувається тому, що мозок не має запасу поживних речовин; запасу кисню вистачає на 2-8 с, глюкози - на 2-3 хв. Це означає, що в кожний момент часу метаболічні потреби головного мозку визначають перфузійні характеристики мозкового кровотоку. Перфузійно-метаболічне поєднання - основа функціонування головного мозку, і його порушення призводить до дисфункції мозкової діяльності, розвитку когнітивних, емоційно-вольових порушень, що значною мірою знижує якість життя пацієнтів і потребує своєчасного призначення терапії для того, щоб вчасно впоратися з цими порушеннями на ранніх, а не на пізніх стадіях.

Встановлено, що адекватність забезпечення мозкової діяльності визначається не загальною перфузією крові через головний мозок, а змінами кровотоку в окремих ділянках мозкової тканини, що виявляють у даний момент часу максимальну нейронну активність. Підвищення активності нейронів супроводжується підвищенням споживання кисню усіма елементами нейроваскулярного блоку, яке забезпечується додатковим притоком крові, що несе кисень до цього регіону, тобто формуванням феномену «функціональної гіперемії». Таким чином дуже вразливими стають функціонально активні ділянки мозку, які беруть безпосередню участь у забезпеченні його інтегративної діяльності.

У дослідженнях показано, що вже на ранніх стадіях порушення мозкового кровообігу відбувається функціональне роз'єднання основних елементів нейроваскулярних одиниць: перерозподіл перфузії на користь активно працюючих нейронів стає неможливим, що призводить до функціональної інак- тивації останніх. Це призводить до порушення пам'яті, уваги, інших інтегративних пізнавальних функцій. На сьогодні доведено, що важливим фактором, який призводить до порушення діяльності нейроваскулярних одиниць, $\epsilon$ ендотеліальна дисфункція на рівні дрібних судин, що викликає зниження їх реактивності і, відповідно, дефіцит перфузії активних ділянок головного мозку [9].

На основі даних, отриманих у дослідженнях, на даний час виявлено найбільш вразливі ділянки головного мозку, значущі для формування нейропсихологічних порушень. Це різні відділи кори мозку - дорсолатеральна префронтальна, орбітофронтальна кора, вентральна ділянка стовбуру. Незважаючи на те що тут відмічається дуже висока нейропластична активність, в той самий час ці ділянки дуже вразливі щодо порушень когнітивних функцій $[10,11]$. Останнім часом створена модель взаємозв'язку ураження структур головного мозку з формуванням психопатологічної симптоматики, в якій, окрім вищезазначених ділянок, суттєву роль відіграє біла речовина, що відповідає за швидкість та ефективність обробки інформації. Величезну роль відіграє гіпокампальна ділянка, мигдалина, що відповідає за емоційне «навчання», страх та тривогу, передня скронева звивина і т.д. Це свідчить про те, наскільки вразливий головний мозок, і яка кількість структур бере участь у формуванні пізнавальних, емоційно-вольових функцій тощо.

Нейрокогнітивні порушення $\epsilon$ багатофакторною патологі$\epsilon ю$. Важливим етіологічним чинником $\epsilon$ церебральна хвороба дрібних судин. Церебральна хвороба дрібних судин - повільно прогресуюче захворювання, частка якого становить 20-25\% усіх інсультів, до 45\% випадків деменції. На початкових етапах розвитку ця патологія характеризується ледь помітними клінічними і морфологічними особливостями, але часто переходить у хронічну васкулопатію, що призводить до інвалідності за рахунок розвитку і прогресування судинних когнітивних порушень, депресії, порушення ходи. Хвороба дрібних судин головного мозку відображає процеси дифузного захворювання, що уражують перфоруючі церебральні артеріоли, капіляри, венули і в подальшому - білу і глибоку сіру речовину. Особливості ангіоархітектоніки судин мікроциркуляторного русла - причина їх вибіркового ураження (підвищене гемодинамічне навантаження на артеріальну стінку призводить до найбільших морфологічних змін). Порушення в системі мікроциркуляторного русла мають достатньо сумні наслідки і призводять до морфологічних змін структур головного мозку. МРТ-характеристика маркерів хвороби дрібних судин включає гіперінтенсивність білої речовини, лакуни, розширення глибоких периваскулярних просторів, кортикальну атрофію, фокальний корковий поверхневий сидероз, гострі лакунарні німі і клінічно значущі церебральні мікроінфаркти і глибокі церебральні мікрокрововиливи [12]. Ці зміни клінічно проявляються судинними когнітивними порушеннями, емоційно-вольовими порушеннями, депресією, постуральними розладами.

Патологія дрібних судин у 2 рази підвищує ризик мозкових катастроф і пов'язана з геморагічними ускладненнями антитромботичної терапії і системного тромболізису, негативно впливає на розвиток і перебіг інших неврологічних хвороб, зокрема хвороби Альцгеймера і Паркінсона. Саме хвороба дрібних судин $\epsilon$ субстратом судинних захворювань головного мозку з хронічним перебігом, що проявляються розладами вищих психічних функцій. Перебіг хвороби дрібних судин асоціюється з прогресуванням когнітивних, емоційно-вольових порушень. Тому оцінка динаміки церебральної хвороби дрібних судин - дуже важливе завдання. Оцінити ії можна, аналізуючи ті морфологічні зміни, які відбуваються в структурах головного мозку.

В одному з досліджень вивчали динаміку церебральної хвороби дрібних судин протягом 9 років з послідовними оцінками на етапі включення, через 5 років і наприкінці дослідження. Оцінювали об'єм гіперінтенсивної білої речовини за допомогою напівавтоматичної сегментації і вручну оцінили 
лакуни і мікрокрововиливи. Класифікували вихідну тяжкість церебральної хвороби дрібних судин як легку, середню або тяжку відповідно до модифікованої шкали Fazekas. Встановлено, що учасники з помірною та тяжкою вихідною гіперінтенсивністю білої речовини мали високу ймовірність прогресування церебральної хвороби дрібних судин, тоді як учасники з легкою вихідною гіперінтенсивністю білої речовини показали помірне прогресування протягом 9 років. Прогресування гіперінтенсивності білої речовини головного мозку асоціювалося з наростанням ії атрофії в другій половині дослідження. Нові лакуни виявлені у 20,3\% учасників дослідження, їх частота була вищою у 2-й період спостереження, ніж у 1-й (3,5 та $2,7 \%$ на рік). У $18,9 \%$ учасників за 9 років виникли нові мікрокрововиливи (2,2\% на рік), частота яких у 2-й період спостереження була вищою, ніж у 1-й (4,2 та 1,7\% на рік). У деяких учасників відмічений регрес маркерів хвороби дрібних судин. Так, зменшення об'єму гіперінтенсивності білої речовини відмічали у 9,4\%, регрес мікрокрововиливів і лакун через 9 років спостереження - у 5,7\% учасників [13]. Тобто процес динамічний, і у деяких хворих він прогресує із розвитком когнітивних порушень, у інших - відбувається регрес маркерів хвороби дрібних судин. Таким чином, саме церебральна хвороба дрібних судин повинна розглядатися у якості найважливішої терапевтичної мішені на ранніх стадіях захворювання саме тоді, коли ще можна вплинути, і морфологічні зміни ще не надто сильно виражені, а, можливо, їх зовсім немає.

Етіопатогенетичні підтипи церебральної хвороби дрібних судин:

- спорадична неамілоїдна мікроангіопатія (найчастіше);

- спорадична і спадкова церебральна амілоїдна ангіопатія;

- спадкова церебральна хвороба дрібних судин (CADASIL, CARASIL, MELAS, хвороба Фабрі, церебральна хвороба дрібних судин на фоні мутації гена COL4A1 та ін.);

- запальна та імуноопосередкована церебральна хвороба дрібних судин;

- венозний колагеноз;

- інші варіанти [14].

Спорадична неамілоїдна мікроангіопатія має вікасоційований характер і розвивається під впливом атеросклерозу, АГ, цукрового діабету, а також інших серцево-судинних факторів ризику [15]. У патологічний процес залучаються переважно дрібні перфоруючі артерії в ділянці базальних ядер і глибокої білої речовини, які уражуються за механізмом артеріолосклерозу, фібриноїдного некрозу, ліпогіалінозу, дистального атеросклерозу і формування мікроаневризм.

Артеріальна гіпертензія - головна причина хвороби дрібних судин і найбільш значущий прогностичний фактор деменції. Це головна причина всіх морфологічних змін головного мозку, які відмічають у хворих із тривалим перебігом АГ, які погано лікуються, у яких розвиваються когнітивні порушення. Розвиток деменції і когнітивних порушень у хворих на АГ пов'язаний із гіпоперфузією головного мозку [16]. У дослідженні зв'язку загальної оцінки захворювання дрібних судин з вихідним артеріальним тиском, преморбідним артеріальним тиском і анамнезом АГ за участю $>1000$ пацієнтів із транзиторною ішемічною атакою/ішемічним інсультом у $45 \%$ з них не встановлена АГ до появи маркерів хвороби дрібних судин. Показано, що середній преморбідний рівень до появи морфологічних змін головного мозку, які $є$ маркерами хвороби дрібних судин, значною мірою асоційований з подальшою вираженістю проявів хвороби дрібних судин, виявлених за допомогою магнітно-резонансної томографії (МРТ), і тяжкістю когнітивних порушень [17].

Субклінічне ураження головного мозку при АГ $є$ актуальною проблемою. Встановлено, що при АГ відбувається підвищення жорсткості великих артерій, змінюються параметри пульсової хвилі, підвищується центральний пульсовий тиск, який впливає на малі судини більш високою пульсацією, знижується тиск у мікроциркуляторному руслі (рис. 5), при цьому периферичний пульсовий артеріальний тиск залишається нормальним.
Рисунок 5 МозокіАГ

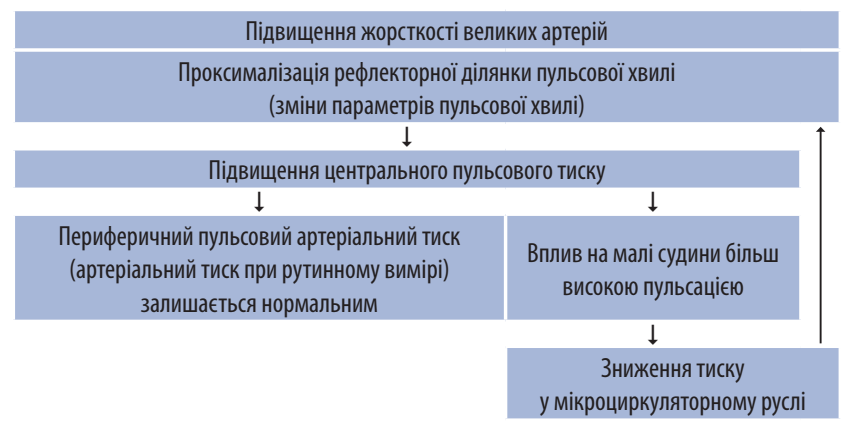

Клінічно у даної категорії хворих ранніми симптомами $\epsilon$ розлади тривожно-депресивного спектру. «Німі» інфаркти підкоркової локалізації, дифузні зміни білої речовини призводять до розвитку синдрому судинної деменції, в рамках якого відмічають різноманітні суб'єктивні скарги неврологічного і соматичного характеру. На сьогодні створена ціла гіпотеза щодо існування васкулярної депресії [18].

Ураження базальних гангліїв, глибоких відділів білої речовини головного мозку відіграють ключову роль у пізнавальних процесах у даної категорії хворих. Судинні когнітивні порушення характеризуються:

- зниженням темпу пізнавальної діяльності (брадифренія);

- коливанням рівня концентрації уваги (флуктуація);

- порушенням керуючих функцій головного мозку (зниження інтелектуальної гнучкості - інертність, персеверації, зниження когнітивного контролю - імпульсивність, зниження критики);

- порушенням пам'яті за типом недостатності відтворення;

- розвитком конструктивної диспраксії.

Динаміка вираженості когнітивних розладів $\epsilon$ індикатором прогресування основного патологічного процесу й ефективності профілактичних заходів.

Стенози артерій атеросклеротичного генезу нерідко до певного моменту бувають безсимптомними, але при цьому вони можуть викликати гемодинамічну перебудову артерій на ділянці, розташованому дистальніше за атеросклеротичний стеноз. Відбувається вторинна перебудова судин мікроциркуляторного русла з розвитком клінічних проявів, що відображають ангіоенцефалопатію (тривожно-депресивні розлади, когнітивні порушення).

Основними механізмами формування когнітивної дисфункції у пацієнтів із цукровим діабетом $\epsilon$ мікро- та макроангіопатії, центральна діабетична нейропатія, які супроводжуються розвитком оксидантного стресу, запаленням та аутофагією у структурах мозку. Клініка діабетичної енцефалопатії формується повільно. Спочатку має перебіг без явних неврологічних і нейропсихологічних симптомів. Першими симптомами $\epsilon$ астенічні, емоційні прояви. Дослідження в різних етнічних групах показали зв'язок між цукровим діабетом 2-го типу, помірним когнітивним зниженням і хворобою Альцгеймера. Так, у дослідженні Honolulu-Asia Aging Study (2012) виявлено підвищення ризику розвитку хвороби Альцгеймера у 1,8 раза і судинної деменції у 2,3 раза [19].

Крім того, в дослідженнях встановлений зв'язок між тяжкістю порушення функції нирок і візуалізуючими біомаркерами хвороби дрібних судин, які також характерні при АГ та цукровому діабеті.

Виявлені взаємозв'язки дозволяють говорити про континуум, складовими якого $\in \mathrm{A}$, хронічна хвороба нирок, цукровий діабет і хвороба дрібних судин, що $є$ значущими факторами нейрокогнітивного дефіциту, який нерідко поєднується з нейросенсорними порушеннями ішемічного генезу. Найбільш часто розвиваються ішемічні кохлеовестибулярні синдроми (гострі або хронічні) при наявності недостатності кровообігу в артеріях, які кровопостачають внутрішнє вухо, корінець VIII нерва, а також вестибулярні ядра і провідні шляхи. 
Патогенетичними факторами кохлеовестибулярних синдромів, крім ішемії, $\epsilon$ порушення трофіки рецепторів лабіринту і лабіринтозалежних структур головного мозку і метаболізму в результаті захворювань судин головного мозку різного генезу.

Отоневрологічне дослідження пацієнтів із нейросенсорною туговухістю без суб'єктивних порушень статичної і динамічної рівноваги дозволяє виявити задіяність вестибулярного аналізатора у $>80 \%$ випадків.

Фактори судинного ризику $\epsilon$ предикторами розвитку не тільки судинних когнітивних порушень, а й хвороби Альцгеймера. Баготочисельні морфологічні співставлення свідчать про високу коморбідність цереброваскулярних та нейродегенеративних захворювань, що послужило основою для розвитку концепції змішаної деменції, яка базується на спільності факторів ризику, взаємному впливі судинного і нейродегенеративного процесу на патогенетичному рівні. Хронічна ішемія і гіпоксія головного мозку $є$ факторами ризику розвитку церебрального амілоїдозу - головної патогенетичної події хвороби Альцгеймера. Таким чином, хронічна недостатність мозкового кровообігу призводить до розвитку нейродегенеративного процесу. Крім того, інфаркти головного мозку сприяють більш швидкій клінічній маніфестації асимптомного або малосимптомного нейродегенеративного процесу.

Про супутню хворобу Альцгеймера свідчать:

- більш виражені порушення пам'яті;

- виражене більшою мірою порушення пам'яті на нещодавні події порівняно з віддаленими (закон Рібо);

- специфічні особливості мнестичних розладів, що свідчать про первинну недостатність запам'ятовування (не відтворення);

- значна різниця безпосереднього і відтермінованого відтворення, порушення впізнавання у пробах з множинним вибором, неефективність підказок при відтворенні, вплетіння стороннього матеріалу при відтворенні (пацієнт намагається вгадати правильну відповідь);

- недостатність номінативної функції мови (порушене називання предметів) за відсутності післяінсультної афазії.

Значним фактором, який призводить до когнітивних порушень, $є$ черепно-мозкова травма. Метааналіз 15 досліджень, проведених протягом 10 років, показав, що в групі осіб, які перенесли черепно-мозкову травму, ризик розвитку хвороби Альцгеймера на $60 \%$ вищий [20]. Оглядове дослідження, що уточнювало роль черепно-мозкової травми у розвитку хвороби Альцгеймера, виявило взаємозв'язок із генотипом АPOE [21]. Багаторічне дослідження за участю $>5$ тис. пацієнтів підтвердило значення черепно-мозкової травми як фактора ризику розвитку хвороби Альцгеймера і встановило тенденцію до більш раннього початку за її наявності [22]. Деякі дослідження свідчать про можливість навіть нетяжкої черепно-мозкової травми виступати у якості фактора ризику розвитку нейродегенерації [23].

Суттєву роль у формуванні когнітивних порушень відіграє коронавірусна хвороба. Враховуючи патофізіологію коронавірусної хвороби (пряме вірусопосередковане ураження клітин, порушення регуляції ренін-ангіотензинової системи, пошкодження ендотеліальних клітин і запалення тромбів, порушення регуляції імунної відповіді і гіперзапалення, викликане інгібуванням передачі сигналів інтерферону вірусом, виснаженням Т-клітин і продукцією прозапальних цитокінів) слід також враховувати, що у пацієнтів з COVID-19 часто виникає тяжка гіпоксія, внаслідок якої може розвинутися неврологічне ураження у вигляді зниження рівня свідомості і коми. Політропність вірусу SARS-CoV-2 визначила поліморфність клінічних проявів інфекції і специфічність ураження нервової системи. SARS-CoV-2 пов'язаний с ACE2, що експресується у нейронах і нейроглії. Нервові клітини, що експресують ACE2, знаходяться в циркумвентрикулярних органах, таких як субфорний орган, паравентрикулярне ядро гіпоталамуса, ядро одиночного тракту і в ростральному вентролатеральному відділі продовгуватого мозку. Усі ці ділянки мають слабкий захист гематоенцефалічного бар'єру і беруть участь в регуляції серцево-судинної системи і дихання. Інфекція, викликана SARS-CoV-2, запускає реактивний астрогліоз і активацію мікроглії. Нейротропні віруси (коронавіруси) здатні активувати макрофаги, мікроглію і астроцити та індукувати прозапальний стан. Первинні посіви гліальних клітин, інфікованих коронавірусом, секретують такі фактори, як інтерлейкін-6, -12, -15, фактор некрозу пухлини-а, призводячи до стану хронічного запалення, що відповідає за пошкодження головного мозку. Вірусна інфекція головного мозку може проявлятися множинними неврологічними і психіатричними наслідками як в гостру фазу захворювання, так і у віддалений період. Зараження SARS-CoV-2, навіть у помірних клінічних випадках призводить до порушення вищих психічних функцій з виникненням делірію, гострого психозу, загострення легких когнітивних порушень або з прискоренням деменції, пов'язаної з різними нейродегенеративними станами, включаючи хворобу Альцгеймера [24]. Концептуально нейрозапалення робить внесок у патологічний розвиток нейродегенерації і часто розглядається як загальна, навіть поєднувальна, ознака нейродегенерації, тоді як інфекція головного мозку і ішемічні інсульти самі по собі можуть запускати нейродегенеративний процес і провокувати розвиток деменції. До того ж страх, який породжує ця інфекція, безумовно, погіршує перебіг багатьох хронічних захворювань і може чинити негативний вплив на інтегративну діяльність головного мозку. Страх - дуже сильна негативна емоція.

Тактика ведення хворих із когнітивним і нейросенсорним дефіцитом включає: корекцію факторів ризику, корекцію емоційно-вольових порушень, немедикаментозні методи, цитопротекторну терапію та немедикаментозні методи.

Один із препаратів, який може застосовуватися при вищезазначених станах, - Нейроплант, 1 таблетка якого містить 300 мг сухого екстракту із трави звіробою (Hypericum perforatum), збагаченої гіперфорином, який: інгібує зворотне захоплення серотоніну, норадреналіну і дофаміну, стимулює утворення серотоніну у нейронах головного мозку, впливає на ГАМК-ергічну і глутаматергічну системи мозку (у низьких дозах стимулює вироблення ацетилхоліну, у високих - пригнічує його зворотне захоплення).

Показання до застосування препарату Нейроплант: лікування депресивних епізодів легкого ступеня. Препарат призначають внутрішньо по 1 таблетці 3 рази на добу протягом не менше 4-6 тиж.

Дані подвійного сліпого рандомізованого порівняльного дослідження ефективності препарату Нейроплант та пароксетину підтвердили відповідність клінічного ефекту та швидкості динаміки показників оцінки депресивних порушень. При зіставній ефективності з пароксетином Нейроплант продемонстрував кращий профіль безпеки: хорошу переносимість і низький ризик розвитку побічних ефектів. Нейроплант, на відміну від антидепресантів, не викликає звикання та синдрому відміни, не потребує титрації дози та постійного спостереження у лікаря. При лікуванні препаратом Нейроплант не спостерігається збільшення маси тіла.

Ще один засіб для підвищення рівня енергії і боротьби зі стресом - препарат Вітанго, 1 таблетка якого містить 200 мг сухого екстракту коренів родіоли рожевої (Rhodiola rosea). Вітанго дає змогу організму пристосовуватися до стресових умов. Він виявляє свої адаптогенні властивості, модулюючи гіпоталамо-гіпофізарно-надниркову вісь, яка відіграє першорядну роль в організації реакції організму на стрес. Крім того, Вітанго нормалізує рівень та активність нейротрансмітерів у ЦНС. Тим самим він усуває спричинене стресом порушення апетиту, опорно-рухової активності та сексуальної функції, а також покращує вироблення клітинної енергії за рахунок підвищення рівня аденозинтрифосфату.

Клінічні дослідження Вітанго демонструють клінічно значуще зменшення вираженості симптомів, пов'язаних зі стресом, таких як фізична та розумова втома, виснаження, дратівли- 
вість, погіршення настрою та здатності зосереджуватися, після 4-8 тиж лікування. Клінічне дослідження 12 тиж лікування виявило здатність лікарського засобу підвищувати індивідуальну стресостійкість і внаслідок цього знижувати ризик розвитку синдрому вигорання. Здатність Вітанго запобігати стресу підтверджена в іншому дослідженні після 12 тиж лікування, яке позитивно вплинуло на увагу та розподіл ментальних ресурсів у осіб, які входять до групи ризику щодо симптомів стресу.

Подолати внутрішнє напруження, тривогу та нормалізувати сон значною мірою допомагає препарат Лазея, який містить високостандартизований екстракт Lavandula angustifolia, активним компонентом якого $\epsilon$ сілексан (Silexan ${ }^{\oplus}$ ). Механізм дії препарату реалізується за рахунок пригнічення і поглинання глутамату і ре-

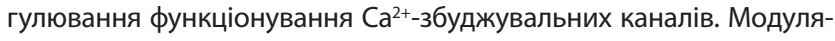
ція пресинаптичних каналів зумовлює зменшення надходження $\mathrm{Ca}^{2+}$ і знижує збудження нейронів, модуляція ГАМК-рецепторів і пригнічення захоплення глутамату викликають виражений анксіолітичний ефект. Лазея може бути рекомендована як альтернатива препаратам групи бензодіазепінового ряду або селективним інгібіторам зворотного захоплення серотоніну (CI33C) з метою зменшення вираженості генералізованих тривожних розладів у дорослих та дітей віком >12 років. Лазея за результатами багатьох досліджень продемонструвала зіставну ефективність з лоразепамом (препаратом групи бензодіазепінового ряду) і пароксетином (препаратом групи CI33C), маючи кращий профіль безпеки та переносимості. Лазея порівняно з препаратами групи СІ33С та бензодіазепінами не викликає звикання, не впливає або незначно впливає на швидкість реакції при керуванні транспортними засобами або роботі з іншими механізмами, не впливає на сексуальну функцію, не призводить до збільшення маси тіла, має зручний режим прийому - лише 1 капсула на добу, може застосовуватися тривалий час без синдрому відміни.

Високим рівнем доведеної ефективності при когнітивних порушеннях, за результатами системних оглядів та метааналізів, характеризується високостандартизований екстракт гінкго білоба (EGb 761) [25-28]. В Україні зареєстровані оригінальні препарати високостандартизованого EGb $761^{\circledR}$ Мемоплант (40 мг в 1 таблетці), Мемоплант форте (80 мг в 1 таблетці) та Тебокан (120 мг в 1 таблетці). У рекомендаціях Всесвітньої федерації товариств з психіатрії (World Federation of Societies of Biological Psychiatry - WFSBP) з лікування хвороби Альцгеймера і різних видів деменції в переліку рекомендованих препаратів зазначено використання EGb $761^{\circledR}$ в дозі 240 мг на будь-якій стадії захворювання: як монотерапія, так і у складі комбінованої терапії.

Стандартизований екстракт гінкго білоба EGb 761:

- виявляє нейропротекторну активність (антигіпоксичні ефекти, радикальне очищення, збільшення кількості антиоксидантних ферментів, покращення функції мітохондрій, покращення кліренсу білка, індукування нейрогенезу);

- впливає на баланс нейротрансмітерів (поліпшення навчання і пам'яті, зменшення вираженості симптомів, викликаних стресом, слабка антидепресантна й анксіолітична активність, підвищення концентрації дофаміну в корі головного мозку, підвищення довготривалого потенціювання);

- покращує кровообіг, особливо в ділянках мікроциркуляції (покращання мозкового та периферичного кровообігу, модулювання проникності судин, попередження дисфункції ендотелію);

- покращує реологічні характеристики крові.

Екстракт гінкго білоба включений в Уніфікований клінічний протокол первинної, вторинної (спеціалізованої), третинної (високоспеціалізованої) та паліативної медичної допомоги «Деменція» в Україні, а також в багатьох інших країнах світу [29].

Препарати компанії Dr. Willmar Schwabe Pharmaceuticals (ексклюзивний представник в Україні «Альпен Фарма АГ», Швейцарія) Мемоплант, Мемоплант форте, Тебокан, Нейроплант, Лазея, Вітанго сприяють збереженню ментального здоров'я пацієнтів і можуть бути рекомендовані в комплексному лікуванні когнітивних та нейросенсорних порушень.
Список використаної літератури/References:

1. Rema V., Armstrong-James M., Ebner F.F. (1998) Experience-Dependent Plasticity of Adult Rat S1 Cortex Requires Local NMDA Receptor Activation. J. Neurosci., 18(23): 10196-10206. DOI: https://doi.org/10.1523/JNEUROSCI.18-23-10196.1998

2. Garraghty P.E., LaChica E.A., Kaas J.H. (1991) Injury-induced reorganization of somatosensory cortex is accompanied by reductions in GABA staining. Somatosens Mot. Res., 8(4): 347-354. doi: 10.3109/08990229109144757

3. Weiller C., Rijntjes M. (1999) Learning, plasticity, and recovery in the central nervous system. Experiment. Brain Res., 128: 134-138.

4. Bütefisch C.M. (2004) Plasticity in the human cerebral cortex: lessons from the normal brain and from stroke. Neuroscientist., 10(2): 163-73. doi: 10.1177/1073858403262152

5. Roy S., Zhang B., Lee V.M.-Y., Trojanowski J.Q. (2005) Axonal transport defects: A common theme in neurodegenerative diseases. Acta Neuropathologica, 109(1): 5-13. D01:10.1007/s00401-004-0952-x

6. Fuchs E., Flügge G. (2014) Adult neuroplasticity: More than 40 years of research. Neural Plasticity, Article 541870. https://doi.org/10.1155/2014/541870

7. Shaffer J. (2016) Neuroplasticity and Clinical Practice: Building Brain Power for Health. Front. Psychol., 7: 1118. doi: 10.3389/fpsyg.2016.01118

8. Zilles K. (1992) Neuronal plasticity as an adaptive property of the central nervous system. Ann. Anat., 174(5): 383-391. doi: 10.1016/50940-9602(11)80255-4

9. Chen B.R., Kozberg M.G., Bouchard M.B. et al. (2014) A critical role for the vascular endothelium in functional neurovascular coupling in the brain. J. Am. Heart Assoc., 3(3): e000787. doi: 10.1161/JAHA.114.000787

10. Salmond C.H., Chatfield D.A., Menon D.K. et al. (2005) Cognitive sequelae of head injury: involvement of basal forebrain and associated structures. Brain, 128(Pt 1): 189-200. doi: 10.1093/brain/awh352

11. Kraus M.F., Susmaras T., Caughlin B.P. et al. (2007) White matter integrity and cognition in chronic traumatic brain injury: a diffusion tensor imaging study. Brain, 130(Pt 10): 2508-2519. doi: 10.1093/brain/awm216

12. Wardlaw J.M., Smith E.E., Biessels G.J. et al. (2013) Neuroimaging standards for research into small vessel disease and its contribution to ageing and neurodegeneration. Lancet Neurol., 12(8): 822-838. doi: 10.1016/S1474-4422(13)70124-8

13. van Leijsen E.M.C., van Uden I.W.M., Ghafoorian M. et al. (2017) Nonlinear temporal dynamics of cerebral small vessel disease: The RUN DMC study. Neurology, 89(15): 1569-1577. doi: 10.1212/WNL.0000000000004490

14. Pantoni L. (2010) Cerebral small vessel disease: from pathogenesis and clinical characteristics to therapeutic challenges. Lancet Neurol., 9(7): 689-701. doi: 10.1016/ S1474-4422(10)70104-6

15. Charidimou A., Pantoni L., Love S. (2016) The concept of sporadic cerebral small vessel disease: A road map on key definitions and current concepts. Int. J. Stroke, 11(1): 6-18. doi: 10.1177/1747493015607485

16. Wolters F.J., Zonneveld H.I., Hofman A. et al. (2017) Cerebral Perfusion and the Risk of Dementia: A Population-Based Study. Circula-tion, 136(8): 719-728. doi: 10.1161/ CIRCULATIONAHA.117.027448

17. https://www.ndcn.ox.ac.uk/research/oxvasc

18. Sneed J.R., Culang-Reinlieb M.E. (2011) The vascular depression hypothesis: An update. Am. J. Geriatr. Psychiatry, 19(2): 99-103.

19. Gelber R.P., Launer L.J., White L.R. (2012) The Honolulu-Asia Aging Study: epidemiologic and neuropathologic research on cognitive impairment. Curr. Alzheimer Res., 9(6): 664-672. doi: 10.2174/156720512801322618

20. Fleminger S., Oliver D.L., Lovestone S. et al. (2003) Head injury as a risk factor for Alzheimer's disease: the evidence 10 years on; a partial replication. J. Neurol. Neurosurg. Psychiatry, 74(7): 857-862. doi: 10.1136/jnnp.74.7.857

21. Van Den Heuvel C., Thornton E., Vink R. (2007) Traumatic brain injury and Alzheimer's disease: a review. Prog. Brain Res., 161: 303-316. doi: 10.1016/500796123(06)61021-2

22. Mendez M.F., Paholpak P., Lin A. et al. (2015) Prevalence of Traumatic Brain Injury in Early Versus Late-Onset Alzheimer's Disease. J. Alzheimers Dis., 47(4): 985-993. doi: 10.3233/JAD-143207

23. Gavett B.E., Stern R.A., Cantu R.C. et al. (2010) Mild traumatic brain injury: a risk factor for neurodegeneration. Alzheimers Res. Ther., 2(3): 18. doi: 10.1186/alzrt42

24. Fotuhi M., Mian A., Meysami S., Raji C.A. (2020) Neurobiology of COVID-19. J. Alzheimers Dis., 76(1): 3-19. doi: 10.3233/JAD-200581

25. Gauthier S., Schlaefke S. (2014) Efficacy and tolerability of Ginkgo biloba extract EGb $761^{\circ}$ in dementia: a systematic review and meta-analysis of randomized placebo-controlled trials. Clin. Interv. Aging, 9: 2065-2077. doi: 10.2147/CIA. S72728 
26. Savaskan E., Mueller H., Hoerr R. et al. (2018) Treatment effects of Ginkgo biloba extract EGb $761^{\circledR}$ on the spectrum of behavioral and psychological symptoms of dementia: meta-analysis of randomized controlled trials. Int. Psychogeriatr., 30(3): 285-293. doi: 10.1017/S1041610217001892

27. Tan M.-Sh., Yu J.-T., Tan Ch.-Ch. et al. (2015) Efficacy and adverse effects of ginkgo biloba for cognitive impairment and dementia: a systematic review and metaanalysis. J. Alzheimers Dis., 43(2): 589-603. doi: 10.3233/JAD-140837
28. Hashiguchi M., Ohta Y., Shimizu M. et al. (2015) Meta-analysis of the efficacy and safety of Ginkgo biloba extract for the treatment of dementia. J. Pharm. Health Care Sci., 1: 14. doi: 10.1186/s40780-015-0014-7

29. Ministry of Health of Ukraine (2016) Order of the Ministry of Health of Ukraine dated 19.07.2016 № 736 «On approval and implementation of medical and technological documents for standardization of medical care for dementia» (https://dec.gov.ua/wp-content/uploads/2019/11/2016_736_ykpmd_dem.pdf). (In Ukr.).

\section{Відомості про автора:}

Дзяк Людмила Антонівна - доктор медичних наук, професор, член-кореспондент НАМН України, заслужений діяч науки і техніки України, лауреат Державної премії України, завідувач кафедри нервових хвороб та нейрохірургії факультету післядипломної освіти державного закладу «Дніпровський державний медичний університет», Дніпро, Україна.

\section{Адреса для кореспонденції:}

Дзяк Людмила Антонівна

49044, Дніпро, вул. Вернадського, 9

\section{Information about the author:}

Dzyak Lyudmyla A. - Doctor of Medical Sciences, Professor, Corresponding Member of the National Academy of Medical Sciences of Ukraine, Honored Worker of Science and Technology of Ukraine, Laureate of the State Prize of Ukraine, Head of the Department of Nervous Diseases and Neurosurgery, Dnipro State Medical University, Dnipro, Ukraine.

\section{Address for correspondence:}

Lyudmyla Dzyak

49044, Dnipro, Vernadsky str., 9

Надійшла до редакції/Received: 30.06.2021 Прийнято до друку/Accepted: 05.07.2021

ТЕСТОВІ ЗАПИТАННЯ

(один або декілька правильних варіантів відповідей на кожне запитання)

1. Які захворювання призводять

до ураження малих судин?
$\square \mathrm{A} \Gamma$
$\square$ патологія печінки
$\square$ розсіяний склероз
$\square$ боковий аміотрофічний склероз

2. Які клінічні ознаки судинних когнітивних порушень?

$\square$ порушення пам'яті на недавні події

$\square$ порушення пам'яті за типом недостатності відтворення

$\square$ недостатність номінативної функції мови

порушення сну
3. Які клінічні ознаки периферичного системного запаморочення?

$\square$ підгострий початок

$\square$ гострий початок, нудота, блювання, зниження слуху

$\square$ відчуття «дурноти», потемніння в очах

$\square$ втрата свідомості

4. У якій добовій дозі необхідно призначати препарат, що містить стандартизований екстракт гінкго білоба, пацієнтам із хворобою Альцгеймера?

$\square 80 \mathrm{Mr}$

$\square 120 \mathrm{Mr}$

$\square 160 \mathrm{Mr}$

$\square 240 \mathrm{Mr}$

\author{
Для отримання сертифіката дайте відповідь \\ на тестові запитання в режимі on-line \\ на сайті журналу \\ www.umj.com.ua \\ або надішліть ксерокопію сторінок \\ з відповідями разом з контактною \\ інформацією за адресою: \\ 01001, Київ-1, a/c «В»-82, ТОВ «МОРІОН»
}

ПІБ
Поштова адреса: індекс
область
район
місто
вулиця
будинок
квартира

Tелефон
E-mail

